\title{
Freud, Said, and the ancient and classical worlds
}

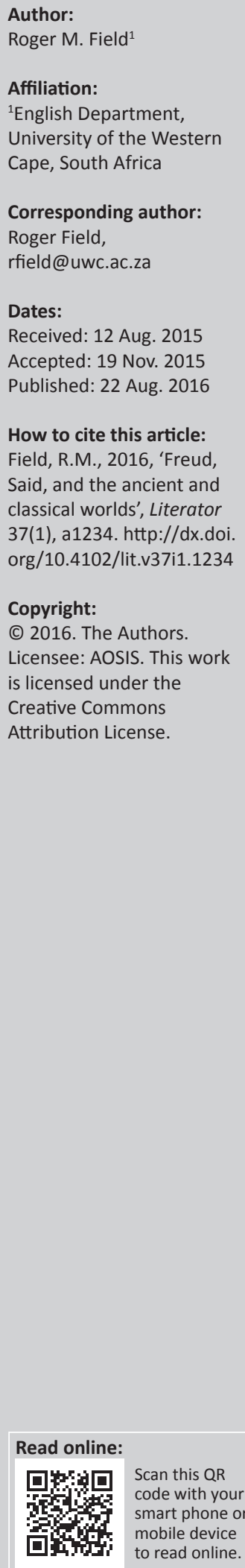

\begin{abstract}
Sigmund Freud's reading of the classics and Greek mythology is well documented. By contrast, Edward Said's reading of Freud has received little attention. This article considers three main issues: how Said and Freud thought about and used ancient and classical Greek literature; the ways in which Said has read Freud reading the ancient and classical worlds; the significance of ambivalence and analogy for these readings. The article concludes that there is a necessary relationship between analogy and ambivalence. Primarily chronological, the reading also draws on Freud's notions of latency and repression to track how Said's approaches to ambivalence and analogy changed. In the case of Said, it is possible to attribute some of these changes to the impact of Bernal's Black Athena, which encouraged him to review the notions of ancient Greek society which underpin Orientalism, and to Bernal's narrative inspiration, Kuhn's The structure of scientific revolutions. Latency and repression make it possible to posit prehistories. Therefore, the article also examines the ways in which Freud and Said have been obliged to assume continuities between prehistory and history, and between individual and mass psychology.
\end{abstract}

Freud, Said en die antieke en klassieke wêreld. Sigmund Freud se lesing van die klassieke en die Griekse mitologie is goed gedokumenteer. In teenstelling daarmee, het Edward Said se lesing van Freud min aandag ontvang. Hierdie artikel stel drie hoofkwessies aan die orde: Wat Said en Freud oor antieke en klassieke Griekse literatuur gedink het en hoe hulle dit gebruik het; die wyse waarop Said Freud se lesing van die antieke en klassieke wêreld gelees het; die betekenis van ambivalensie en analogie vir hierdie lesings. Die gevolgtrekking van die artikel is dat daar'n noodwendige verwantskap tussen analogie en ambivalensie bestaan. Hoofsaaklik chronologies aangepak, steun hierdie lesing ook op Freud se opvattings oor latentheid en repressie om aan te toon hoe Said se opvattings oor ambivalensie en analogie verander het. In die geval van Said, is dit moontlik om sommige van die veranderings toe te skryf aan die impak van Bernal se Black Athena, wat hom aangemoedig het om die opvattings van die antieke Griekse samelewing onderliggend aan Oriëntalisme te heroorweeg, en aan die narratief wat Bernal geïnspireer het, naamlik Kuhn se The structure of scientific revolutions. Latentheid en repressie maak dit moontlik om voorgeskiedenisse postuleer. Die artikel ondersoek derhalwe ook die wyse waarop Freud en Said verplig was om kontinuïteite tussen voorgeskiedenis en geskiedenis, en tussen individuele en massapsigologie te veronderstel.

\section{Introduction}

Sigmund Freud was an avid collector of ancient objects from Greece, Egypt and the Middle East (Armstrong 2005:33-34; Downing 1975:6; Tourney 1965:71), and references to Latin and Greek texts, classical Greek tragedy, archaeology and anthropology abound in his writing. Edward Said, too, relies on archaeology and the classics. In Beginnings: Intention and method, he can only analyse Freud's The interpretation of dreams after he has discussed the classicist, archaeologist and imperialist insurgent T.E. Lawrence. He compares Lawrence's interpretation of the Arab revolt against the Ottoman Empire in the Seven pillars of wisdom to the way that Joyce takes up the Odyssey, so changing the mundane events of that 16th day of June 1904 in Dublin into something with another meaning altogether (Said 1985a:154) ${ }^{1}$.

The 'worlds' in my title are also cultural and imaginative spaces, and I use the terms 'ancient' and 'classical' loosely to cover the period from about 1200-400 BCE. However, the arguments of both writers require a time before that. Where Freud, and to a lesser extent Said, refers to 'pre-historical' 1.An Erasmus Mundus fellowship at the Department of Greek Studies at the Catholic University of Leuven from December 2014
to February 2015 enabled me to complete this article. My thanks to my hosts and colleagues, in particular Prof Peter van Deun, Dr Reinhart Ceulemans, and Dr José Maksimczuk. 
practices, he often relies on Greek mythology to infer the existence of rule- or norm-bound activities for which there is no evidence, but which he believes must have existed in order for later recorded actions to make sense. In what follows, I explore some of what Freud and Said have written about the ancient and classical worlds through four questions. What is the significance of ambivalence and analogy for their readings? How have they thought about and used ancient and classical Greek literature? How has Said read Freud's reading of the ancient and classical worlds? How might a new way of writing about the past or the self that draws on Greek mythology produce new knowledge?

Argument by analogy rests on the assumption that two or more processes or arguments are 'just like or analogous to one another'. For Guttenplan, '[w] hat the arguments share is not a content, but a form or structure' (1996:31; emphasis in original). There are several ways to judge the strength of an analogical argument in order to compare or predict outcomes. These include factors such as the frequency with which an event or process has previously occurred; the number of features the two share; how many features the two do not share; how many relevant points the two share? How many relevant points the two share (Copi 1973:358-360)? After Freud and his contemporary Ferdinand de Saussure, Jacques Lacan's Rome Report - The function and field of speech and language in psychoanalysis (1992) - is probably the most (in)famous source of analogy within psychoanalytic theory, and Richard Armstrong (2005) takes both Freud and Lacan to task for their reliance on this method. It is, he says, 'the mode of flirtation and free play...the somewhat irresponsible and suggestive discursive behavior that promises much but refuses to follow through in extensive detail' (p. 38).

Orientalism (1985b) is not Said's first foray into the classics and psychoanalysis, but in it he lays the foundation for much of what follows. For Said (2013b), Orientalism as discourse and practice predates the Iliad. By that time (760 BCE), the line between the East and the West had already been drawn (1985b:56), and would continue, he later says in:

The clash of definitions', into the 5th century BCE with Herodotus, for whom 'anyone who did not speak Greek was automatically a barbarian, an Other to be despised and fought against. (p. 577)

In this schema, Aeschylus's The Persians (472 BCE) and Euripides's The Bacchae (410 BCE), are particularly significant. The former converts a defeated military and political threat from the East in the form of Xerxes's invading army into passive mourning by Persian women. It establishes the Orient as a place significant for what it has been, equating it with loss or demise. This applies particularly to the last third of the play, from the chorus' speech just before Xerxes's entrance.

For Said, the 'two aspects of the Orient that set it off from the West in this pair of plays will remain essential motifs of European imaginative geography. A line is drawn between the two continents. Europe is powerful and articulate; Asia is defeated and distant' (1985b:56-57). In Orientalism, then, Said does not say that these works were subsequently interpreted as 'a Western style for dominating, restructuring, and having authority over the Orient' (1985b:3). He says that Orientalism starts then and there. Like all texts, Orientalism needs an enabling moment and a textual point of departure, but is this a convincing one? One answer might be that it is no more convincing than Freudian explanations that rely on Greek mythology. In Orientalism, Said speaks for Greece, investing it with a cultural coherence, intellectual homogeneity and aesthetic harmony that we might find in the 18th- or 19th-century Hellenophiles such as Goethe or Hegel, so that 'Greece' might become the first voice of Europe to speak for, and therefore separate itself from, the Orient. The social and geographical imaginary of the Iliad, The Persians and The Bacchae may be 'Greek', and in the epic 'the Greeks' tend to be braver and speak one language, unlike 'the Trojans' (Iliad IV). However, Said overlooks the fact that the Iliad as text shows that Greek and Trojan antagonists have much in common, including the same gods, religious practices, marriage and funeral customs, the use of cattle as a measure of wealth, social and political organisation, military weapons and strategy.

Rather than a personal lesson about tolerance or flexibility, Said sees Euripides's later work as an expression of the 'strangely threatening excesses of Oriental mysteries' (1985b:56). The political lessons which this play teaches the West are to not underestimate the power of irrationality, which the orient can bring into the Western domain when it is weak or internally divided, and to play a strategic power game with the Orient (1985b:57). To make these points, in Orientalism Said focuses on The Bacchae's sociopolitical context: 'foreign ecstatic religions' that gripped the population of Piraeus and Athens during 'the frustrating and increasingly irrational years of the Peloponnesian War' (1985b:56-57). He confirms a distinction between Orientalism and Hellenism, in this instance the systematic valorisation of ancient and classical Greece as the ordered and organising cultural, intellectual, and political foundation of the Western world. Thus, where Orientalism is concerned with exteriority and enduring difference, Hellenism as an expression of cultural supra- or pan-nationalism or -culturalism presents the fantasy of unbroken cultural and political continuity between Greece and Western Europe. This fantasy depends on what Richard Armstrong describes as the 'assumption that the Greeks have an exceptional relationship to [Western] modernity' (2005:181 emphasis in original). This assumption is evident in Jürgen Habermas's claim that in a succession of epochs such as the Renaissance and the Enlightenment, 'the expression "modernity" repeatedly articulates the consciousness of an era that refers back to the past of classical antiquity precisely in order to comprehend itself as the result of a transition from the old to the new' (1979:39).

The canonical Greek texts mentioned earlier provide lessons and information about how the West was won, and how it should continue to deal with the Orient. In keeping with his emphasis on the exteriority of Orientalist discourse, in the 
case of The Persians, Said argues that its performance expresses a foundational analogy between the orchestra (the space in front of the actors in which the chorus performs), which is populated with a chorus of Persian elders who embody Aeschylus's conception of 'the Asiatic world' (Said 1985b:57), and 'the learned envelope of Orientalist scholarship'. The latter holds, manages and watches over an enormous, shapeless 'Asiatic sprawl' (p. 57). In this way, the Iliad and the performances of early and late Greek tragedy express what Said calls strategic location and strategic formation (p. 21 emphasis in original). Where the former refers to the writer's point of view on matters oriental, the latter designates the different ways in which combinations of texts acquire the credentials and authority to speak for the Orient, and to prescribe the rules for engagement with, in the present case, those Greek texts that are Orientalism's point of departure.

There are a number of problems with Said's treatment of The Persians. If all tragedies contain defeat and express loss, the fact that the Persians are defeated and express loss does not on its own make them deficient or a metonym for Oriental decline or inferiority. It might have been more productive to note that the chorus refers to 'the Greeks' as a collective identity with a clear political consciousness in contrast to the opulent imperial Persian polity that the chorus catalogues in epic mode, but which is brought down by hubris. Nor does The Persians refer to West/Europe and East enough to make this a founding moment. Here the problem is Said's assertion that Aeschylus and his generation already thought along the lines of West/self-East/other dichotomy. He has to assume that Orientalism had become latent and re-emerged around 900-800 BCE Greece, or that the distinction was already so deeply embedded that it was unspoken common sense, but he refers to so few works that he cannot argue that the West-East divide was an established cultural fact. Furthermore, within Aeschylus's and Euripides's surviving work, the Trojan War, precipitated by Paris' violation of the conventions of hospitality among elites rather than irreconcilable cultural differences between the antagonists, is far more significant. Like Freud before him, Said has to infer the presence of a discourse for which there is no record, but which he believes must have existed in order for subsequent expressions to make sense to an even later society.

At the same time, Said suggests that Orientalism offers the West a means to articulate and manage its own internal conflicts. For the Said of Orientalism, The Bacchae is a social document; it is an example of what in On late style he describes as contemporary social 'reality breaking through' (Said 2007:9). However, by the time he comes to write the latter, The Bacchae and now Iphigenia at Aulis are more significant for their 'lateness', a term Adorno uses in discussions of music. Said too devotes much of On late style to music, and some of it to literature, where lateness has several applications. The most interesting for current purposes is a phase within the history of a genre, or a phase within the creative life of an artist in which his or her work is at odds with the time, their creative path thus far, and with the conventions of the chosen genre. Euripides's plays are late. While it is as easy to discern 'the lineaments of age-old myth' in The Bacchae or Iphigenia at Aulis as it is in his predecessors such as Sophocles and Aeschylus, Euripides refuses their 'sense of reconciliation and closure' (Said 2007:127). So too is Moses and monotheism, says Said in Freud and the non-European. Through questions about Moses' identity, Freud's eponymous work is a response to contemporary political developments, his own personal challenges, and the impossible task of discerning 'the very elements of identity itself' (2004:27-30).

Like Freud before him, Said stresses Euripides's 'primitivism in content' (2007:125) in order to show why contemporary performances (late 1980s and early 1990s) retain the original's enabling and insistent power. To find the source of that power, Said pushes back the plays' origins to a preHomeric social practice that explains the origins of tragedy, and which he evokes with a quotation from Yeats's 'The Magi'. Struggling to understand the Christian crucifixion, the magi draw on the closest parallel with which they are familiar:

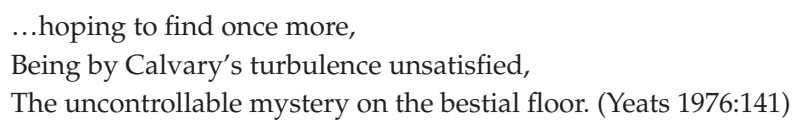

It is possible, says Said echoing Freud, to trace this practice to 'some scarcely remembered beginning point' marked by 'an early yet profoundly disturbing clue' (Said 2007:126). He suggests that the crucifixion disturbs the magi because it has released a repressed desire to remember a practice that precedes recorded history. For Said, following Freud in Totem and taboo (2004:175) and Moses and monotheism (1939:214-215), this pre-Homeric social practice which continues to resist amnesia and disrupt the established familial and social order is the intra-family killing that followed the incest prohibition, and preceded animal sacrifice and tragedy. In The Bacchae, a mother of a son; in Iphigenia at Aulis, a father of a daughter.

Though it would not appear until 1987, 9 years after Orientalism, much of the power which Said attributes to Homer, Aeschylus and Euripides is evident in Martin Bernal's 'Aryan' and 'Ancient' Models of Hellenist scholarship. The first part of Bernal's (1978) three-volume Black Athena: The Afroasiatic roots of classical civilization has become the main reference point for the story of how, from the late 18th century onwards, during the growth of European nationalism, European classicists challenged the Ancient Model, which acknowledged Semitic (Eastern Mediterranean) and African (Egyptian) influences on ancient and classical Greece, including references by Greek writers of that time. However, it was suppressed and replaced by the Aryan Model. The discovery of links between different language groups and the emergence of nationalism and colonial ideology in Western Europe facilitated this replacement. The former made it possible to argue that Greece was invaded and influenced by northern cultures; the latter stressed the contemporary superiority of Western and northern European culture and technology. By design or default, the result was a narrative of unbroken cultural and racial continuity between ancient and classical Greece and the modernising powers of Western 
Europe (Said 1993:16, 2013b:584-585). In effect, the bearers of late 18th and 19th century Western and Northern culture, science and progress were white and racially superior because they were the descendants and inheritors of Greek culture. In the discourse of the time, those descendants displayed distinct national characteristics. Therefore, the ancient Greeks must have been white, and superior to their neighbours, and must have developed independently of them, particularly if those neighbours were now regarded as inferior. In his later essay, A clash of definitions, Said attacks the Aryan Model (2013b:653), highlighting its racist motivations, and elsewhere after the publication of Orientalism he acknowledges some of the problems inherent in its beginning.

Bernal's argument has attracted considerable criticism, including the appropriateness of his metanarrative drawn from Thomas Kuhn's (1970:208) The structure of scientific revolutions. For present purposes, Bernal's research and arguments are less significant than the support of public figures such as Said and Toni Morrison. His work, she says, has influenced her thinking about the 'process and motives' driving literary canon-formation in the United States. In Bernal's writing, 'motive, so seldom an element brought to bear on the history of history, is located, delineated and confronted' (Morrison 1988:132 emphasis in original; Roynon 2013:17-20). Like Said, she focuses on the first volume of Black Athena, possibly because it has the qualities of a revelation, though not necessarily for specialists. The first volume also attacks an entity that Bernal says represents the official, white Western, metropolitan, conservative view of ancient and classical Greece, one that he claims dominated teaching about the Greece of that period and its mythology and literature, and that contributed to Nazi ideology. ${ }^{2}$

Said, too, is concerned with the values of respectability, depth and meaning. Part of his agenda in Beginnings: Intentions and method is to show that through the composition of The interpretation of dreams, and the significance of the Oedipus myth for Freud at this time, he (Freud) is one of several late 19th- and early 20th century writers whose work raises questions about 'beginning and development' in analysis and narrative in three areas: chronology and sequence in the context of suprahistorical entities such as the unconscious; the utility of a mimetic notion of language for describing 'the complexities of human psychology'; the purpose or function of fiction in narrative (Said 1985a:158).

By attending to the palimpsestic features of The interpretation, in which successive editions record Freud's growing realisation of the significance of the Oedipus myth for himself and his own work, Said is able to illustrate the three areas mentioned in the previous paragraph, and to advance his argument by drawing two analogies. One is between Freud and Oedipus. The other is between The interpretation and Oedipus (1985a:169-174). Said accommodates this very

2.Bernal's work makes rehabilitation or reclamation of the classics possible for students and academics more accustomed to a postcolonial perspective.That has been my experience, when I refer to or describe its arguments in my teaching; it generates excitement partially through a sense of conflict and crusade, of the other 'writing back' to the metropole. psychoanalytical excursion by pointing out that the process to which Freud commits himself relies on several interpretive frameworks, and does not assume that the earlier an insight occurs the more significant it must be (p. 169). Freud (1939:116) could also acknowledge the limitations of a particular path or sequence of interpretation. For example in Moses and monothesism he discards but does not remove the limited analogy between on the one hand the survival of Homeric epics into later, though still ancient, Greek society, and on the other hand the revival of the 'old Mosaic religion'. This approach, says Said, enables 'knowledge of a different kind' that is not based on linear or 'additive' principles (1985a:169; emphasis in original).

One of the intriguing features of Totem and taboo and Moses and monotheism is how persistently Freud pursues argument by analogy in order to show in the former that 'savages', children and neurotics think in similar ways, and that individual and mass psychology follow the same path in certain matters. From Said's perspective, Freud developed a way of writing and analysis that 'performed' the material about which he wrote, and that when it came to providing support at a particular point in his argument, or to reach a difficult conclusion, he (Freud) relied very heavily on analogy, elevating it to a first principle. Thus, the analogy between individual and mass psychology is 'not so startling as it appears at first sight; indeed, it is in the nature of an axiom' (Freud 1939:117).

Said notes a significant instance of the Freud-Oedipus analogy: Freud analyses his own dreams and realises that he (too) has an Oedipus complex (desire to take the place of the father in his relationship with the mother by killing him). Here Said comments that 'the text of the Interpretation can be traced back step by step to Freud's own self-analysis' (1985a:172). Playing on Oedipus's fate, he describes Freud's realisation as a 'type of knowledge so devastating as to be unbearable in one's sight, and only slightly more bearable as a subject of psychological interpretation' (p. 170). By subverting patri-lineal order, an order which assumes that the earlier an insight occurs the more significant it must be, Said argues that through Oedipus, Freud (1985a) throws into disarray the progression we have come to regard as 'natural' in life, narrative and analysis:

...one image is then grasped as an inadequate summary of several thoughts; Oedipus is a king whose position in Thebes cannot exhaust his incestuous history; a text is not the sum of its words added together; an author - his scientific detachment and professional discretion notwithstanding - is not free of the unseemly implications of his writing. (p. 171)

Here Said proposes that a particular style of writing that communicates and performs an analogy with the Oedipal disruption, presents a new way of thinking. His point is that through a methodical study of Freud's self-analysis, we can uncover how Freud discovered that 'devastating' knowledge. He argues that the knowledge of an individual's or a society past that we obtain through a new form of writing that performs what it argues produces a new way of thinking. 
In the second analogy between The interpretation and Oedipus, Said addresses several conventions about the relationship between logic and narrative that governed the writing of science, history and fiction in late nineteenth-century Europe, and which Freud chose to avoid. These conventions work in combinations or separately, because they are not all simultaneously compatible. The first convention removes a text in time and space from whatever it describes; it assumes that 'verbal' text always follows 'material' event (1985a:162). By contrast, Freud includes his own dreams and self-analysis in The interpretation, so that he is both word and deed. The second convention refers to the notion of a linear, irreversible movement in which the conclusion must follow from the beginning or premises. Freud departs from this convention when he argues by exclusion to show why his approach is more compelling than his predecessors' and contemporaries', and why his dream self-analysis does not follow a linear path.

Towards the end of his analysis of The interpretation of dreams, Said speculates that in his late works Freud reacted to the prospect of his books 'becoming the fundamental authorising texts of a new science', reacting ambivalently, to the issue of paternity and hierarchy. Freud (1985a:176-177) did so by expanding the areas of knowledge which defined this new science into regions that his work already acknowledged but which were unknowable. He restricted the boundaries of the conscious and extended the terrain of the unconscious. Here Said's point is that Freud used a 'modern' mode of writing that ushered in a new way of thinking that made public the structure of the unconscious, so that the exposed unconscious became the consciousness of modernity. This offers a different response to Armstrong's question, 'How can the growth of the unconscious lead to a progressive expansion of consciousness?', which he answers by referring to debates within the Vienna Psychoanalytical Society in the early 20th Century (2005:207-208). It may be that Said answered the question differently because he read The interpretation through Freud's later works such as Totem and taboo, in which ambivalence plays a key role. There he describes 'ambivalent impulses' as those 'corresponding simultaneously to both a wish and a counter-wish, or operating predominantly on behalf of one of the two opposing trends' (Said 2004:42), where one impulse, usually the antisocial, destructive or feared one is repressed.

Interestingly, Said reverses the Freudian flow of ambivalence. In Totem and taboo and Moses and monotheism, Freud stresses the son's ambivalence towards the father figure, whereas in Beginnings Said refers to Freud's 'repeated analysis of the ambivalent father' (1985a:172). Assuming this is not a (Freudian) slip, Said's point is that in the content and presentation of The interpretation, Freud was an author who became an authority by contravening contemporary narrative and explanatory conventions. He achieved this by exposing the patriarchal order on which they rested. This reversal installs a father figure who is ambivalent, because he uses his authority as a father figure to expose the source of his own power. He also appears in Orientalism. If Orientalism offers the
West a means to acknowledge its internal conflicts without resolving them, as Said's analysis of The Bacchae suggests, then there must be an ambivalence in the West about the legitimacy of its source of authority over itself. Here there is something distinctly Freudian, particularly the Freud of Totem and taboo or Moses and monothesim, about Said's thinking. Totem enables Said to establish a form of continuity between what he says about these Greek texts in Orientalism and On late style. In Freud's four linked essays about exogamy and the expression of the incest prohibition through totemism (Freud 2004:19-20, 3-31, 72, 104-105, 130), ambivalence is a fundamental presupposition. One might describe it as an attitudinal or affective continuity, which makes possible an explanation that is simultaneously 'historical and psychological' (p. 125). In that way, ambivalence facilitates 'arguing back from a comparatively high phase of religious ritual to the lowest one' (1939:154).

Said's comments on the performance of Euripides's, Sophocles's and Aeschylus's tragedies in his own time and at the time of their composition also assume a 'historical and psychological' continuity, and here he is at one with Freud in The interpretation and Totem and taboo. In the former, Freud observes that it is the subject matter of Oedipus Rex, and not its generic qualities, that moves contemporary audiences (p. 364). In the later Totem and taboo, he argues that these same tragedies were 'derived from the historical scene through a process of systematic distortion' (p. 181). Subsequent performances retain the initial significance and purpose, even though they transformed the primal horde, which had previously attacked and killed the 'primal father' (p. 181), into the Chorus; the latter have 'now...exhausted themselves with sympathy and regret', as if 'it was the Hero himself who was responsible for his own sufferings' (p. 181). Thus, where Said focuses on the meaning of the space that the chorus occupies in works which he has already decided initiate an Orientalist discourse, works which simultaneously perform the West's ambivalence towards the authority with which it exercises self-control, for Freud the chorus also expresses ambivalence towards self-control, here through the transformation into a ritual of murder, castration, dismemberment and consumption of the primal father. And this, says Freud (1979:6) in Civilization and its discontents, 'brings us to the more general problem of preservation in the sphere of the mind'.

Freud's argument about modern neurotics, 'savage' people and children flattens out historical differences between those he believes cannot or cannot yet progress beyond narcissism (pp. 103-105). By contrast, he draws on architectural imagery - the value of heritage and the symbolic capital of the built environment - to talk about himself. For the Said of Freud and the non-European, Freud's Athens is 'a city of the mind, a generally more adequate representation of Freud's lifelong dedication to intellectual achievement' (p. 38). That 'city of the mind' rested on a strong foundation of German philhellenism, which underlay his own facility with Latin and Greek, his reading of Heinrich Schliemann and Arthur Evans, and the excavations at Troy, Knossos and Pompeii 
(Freud 1939:114; Tourney 1965:67-68, 70). Athens was not only associated with the serene order of classical architecture, but with myths such as Oedipus and Narcissus. Downing (1975) stresses 'how important it was in his [Freud's] selfanalysis for him to discover himself in relation to the mythical prototype, Oedipus' (p. 10), while according to Tourney, Freud's Oedipus 'represented the primaeval reality' (p. 73). In turn, this rested on claims that Evans and Schliemann had discovered the actual labyrinth beneath Knossos or the actual Troy of the Iliad, and on a circular argument that linked myth, psychoanalysis and scientific respectability. As Tourney explains it, Freud and several of his disciples reinforced how crucial mythology was 'for the understanding of psychoanalytic concepts, as well as a scientific realisation of the meaning of myths through psychoanalytic principles' (p. 73). No wonder that Tourney (1965) goes further, describing this as an obsession (pp. 77-78) on which Freud could build a monument to Oedipus, and himself. (p. 182).

For Freud, Athens and Rome became monuments to his own considerable achievements. In the case of The interpretation of dreams, through adolescent identification with Hannibal, Rome became a reminder of his status as determined outsider. As he became aware of and reacted against anti-Semitism, through his Latin classes Freud (1978:285) identified with the Semitic general. In the case of Civilization and its discontents, he attempts to use Rome, with its juxtapositions of remnants, ruins and buildings across the centuries as an example of the challenges he faced in explaining the relationship between memory, repression and physical deterioration to an audience that was ignorant or unreceptive towards psychoanalysis. He concludes that not even the eternal city of Rome could match the complexity of his own discovery and intellectual construction.

If cultural nationalism refuses a history of mixture or suppresses 'foreign' influences, the better to prove the existence of a pure national culture, so too do elements of what Bernal would later call the Aryan Model. These factors influenced Freud's public record of a self-analysis precipitated by his only visit to Greece. Freud certainly received a 'good education' for the time, persuasive enough to make him remember in 1936 what he had experienced in 1904 when he visited the Athens Acropolis: the Greece of his childhood memories and a purified Aryan vision. In the book, $A$ disturbance of memory on the Acropolis, he sees the Athens of his childhood education and enjoys the realisation that 'all this really does exist, just as we learnt at school!' (p. 449: emphasis in original). Contemporary Greece and Athens leave no impression, and this makes sense because the remnants of imperium and polis had received very different treatments. Rome's abundant signs of the intervening provided him with imperfect spatio-temporal analogies that affirmed his achievements even as he acknowledged his own decline. However, by the late 19th century in Greece following the systematic 'purification of the landscape, by removing all remnants that polluted the material traces of the golden age of the classical period' (Hamilakis 2007:86: emphasis in original), there were few signs of 350 years of Turkish,
Oriental occupation on that acropolis. This created the impression of continuity between classical and contemporary Greece, which Freud's excited response affirms.

In the book, A disturbance of memory on the Acropolis (1991), Freud enacts a looking back to 1904; as part of this re-creation, he steps back even further into his childhood education and the images of ancient Greece and classical Athens that it contains, and he juxtaposes these reconstructions of his memories with the experience of being in the 'actual place' as an adult. To get there, he and his brother had to limit 'filial piety'. Only then could they understand their reluctance to go further in all aspects of their lives than their less-educated, parochial father. 'Disturbance' is less of a disruption and more of an affirmation. It draws on a 'purified' classical Greek landscape in which a mis-en-scène of the cradle of Western civilisation, childhood pleasure and adult success all converge. From Freud's perspective it shows us why, even if Jakob Freud was not a primal father figure and his sons were not a primal horde, it is good to acknowledge (resolve, even) one's ambivalence on father issues. It is possible, Freud implies to challenge the father figure while respecting him, and to make one's own way in the world, relatively happily, while leaving the family intact. The fact that Freud describes his relationship with his father in these terms reminds us that in Freud's world Oedipus is always present, in a 'tangled' (Said 1985a:169) combination of self-analysis and mythological allusion, that wins support from those who take silent, shared pleasure in recognising classical and mythological allusions and who are therefore at home in that discursive world. As Said notes, the mythological character is always already part of a 'community of socially invested values and symbols' (1985a:91).

In the later Freud and the non-European, Said returns to this topic, reinforcing his argument in Beginnings. In the former, he considers the ways in which Freud could and could not think about otherness: 'the Other' that interested Freud is 'recognizable mainly to readers who are well acquainted with the classics of Graeco-Roman and Hebrew Antiquity' (2004:14). Freud challenged many conventions, offering new interpretations, but the tropes and symbols that he used were thoroughly westernised. However, even if he was less interested in the 'primitive' communities living in contemporary colonial territories, he nevertheless stressed what linked 'civilised' and 'primitive societies': 'universal behaviours as the prohibition against incest' (20), which committed the most 'primitive' and 'developed' societies to the same fundamental beliefs and practices of familial and social organisation.

Within Said's larger engagement with late style that includes Freud and the non-European, there are several reasons why he believes Moses and monotheism is significant: Moses was an Egyptian in an ethnic sense; his disposition was not unlike the transcendental entity whose worship and absolute obedience he demanded; he was killed by 'his own' people (Freud 1939:11-85, 2004:28, 33). Here Freud 
repeats his earlier argument in Totem and taboo about the origins of tragedy. He argues that 'the return of the repressed' in 'obscured and distorted' form (1939:113) makes it possible to remember the persistent suppression of that collective act to which Yeats alludes. Freud and Said are equally complicit in this sleight of hand by which an inferred event in the distant past of an ethnic group becomes part of its cultural memory, and therefore its contemporary identity.

By drawing together a sense of profound difference from other cultures which Freud places at the roots of Jewish ethnic, religious and cultural identity and the feeling of incompleteness which finds expression in the tragic genre, Said makes his case that Moses and monotheism is a late text and prepares his listeners and readers for an analysis of the state of Israel, which he shares with Hannah Arendt. For Arendt (2007), writing in 1948:

\begin{abstract}
...if the non-Zionists had wanted to act as genuine realists in Jewish politics, they should have insisted and continued to insist that the only permanent reality in the whole constellation was the presence of Arabs in Palestine, a reality no decision could alter - except perhaps the decision of a totalitarian state, implemented by its particular brand of ruthless force. (p. 394)
\end{abstract}

Said puts the matter similarly in On late style. Instead of opening up to the non-Jewish presence at the heart of Judaism which Freud's Moses affirms, the 'fate' of a post-1948, Europeanised Israel has been 'to hold non-European indigenous peoples at bay for as long as possible' (2004: 41-42). An archaeology driven to prove an unbroken Jewish presence within the expanding state of Israel contributes to this tendency. That archaeology, says Arendt, would lead 'the Palestinian [Israeli] Jews...[to] degenerate into one of those small warrior tribes about whose possibilities and importance history has amply informed us since the days of Sparta' (p. 397). She has in mind Nazi Germany.

From this perspective, it is easier to see why Said shifts his attention from the foundations of Orientalism to the invention of a tradition in the Aryan Model and then to his support for Bernal's thesis, and why the content and structure of Moses and monotheism had such personal and political appeal. For Said, both Bernal and Freud tell him 'a great deal about the possibilities of actually creating a civilisation retrospectively and making that creation into a frozen definition, in spite of the evidence of great hybridity and mixture', and how this relentless drive to prove a pure origin leads to the sort of 'unfortunate results' found in Nazi Germany (2013b:585-586), and which he finds in modern Israel. That is partly why in Culture and imperialism and Reflections on exile Said turns to Bernal and the latter's methodological model or metanarrative - Thomas Kuhn's The structure of scientific revolutions - but without disavowing his Foucauldian debt in Orientalism.

Both Said and Freud regard ancient and classical Greek texts as beginnings. In Orientalism, Said is not concerned with the Iliad and Odyssey as mythical texts. Rather, they are where and when the discourse and practice of Western literature and Orientalism begin. Therefore, they are also a moment of opposition or 'othering' on which this West-East imaginary depends. This is less Freud's concern, in part because his 'other' was largely Western. The heroic epics, which Freud places in the 9th century or 8th century BCE, are the remnants of the records of an earlier, grander civilisation that survived in oral form through the so-called Greek 'dark ages' (1100 and $900 \mathrm{BCE}$ ). The epic is there as an analogy whose history Freud wishes to apply to individual psychology: how forgotten or repressed material can survive or return. If, in Lacan's words, the unconscious is 'structured like a language', it must do so in speech rather than writing. This may be appropriate for the 'talking cure', but it remains an analogy. Argument by analogy is simultaneously attractive and problematic. As Armstrong suggests, analogy facilitates persuasive comparison, provided one does not compare it with other more rigorous forms of argument, dwell too long on the nature of the act of comparison, or on the properties that are compared. For this reason, in Freud's and Said's writing analogy and ambivalence are bound to each other. There can be no analogy without ambivalence.

Said and Freud agree on the plays. While the Homeric works have become texts, the former continue to be performed. It is true that every generation and culture translates and interprets Homer (2009) in different ways, and in this sense 'performs' the epic differently, but we enjoy those 'performances' privately as isolated readers. The plays retain their public function, and while that public has changed greatly over the last 2400 years, both Freud and Said agree that the plays' primitive, or archaic, elements are still evident and powerful.

Several notions of performance permeate the works of Said and Freud analysed here. Both refer to initial and more contemporary theatrical performances of Greek tragedies, stressing the subject matter and its 'pre-historical' sources and significance, rather than the tragic form. While both acknowledge that different stagings may encourage new interpretations, neither accepts that each staging presents the play anew. When Said refers to the initial staging of The Persians, the very characters and their positions become partplayers in the performance of an Orientalist discourse. Freud, too, performs a role for Said, who argues that the design of The interpretation of dreams enacts the concepts and types of argument which the text presents in more abstract form. For Said, Freud speaks the cultural expression of the experience of modernity - modernism. Since the subtitle of Totem and taboo is Some points of agreement between the mental lives of savages and neurotics, Freud uses the term performance differently from Said. Most of the time, it is part of his argument that 'savages' and 'neurotics' feel compelled to carry out certain actions to maintain social and individual cohesion respectively. In both cases, these are heavily prescribed actions within a symbolic or transhistorical space. Occasionally, Freud uses the term in an artistic sense, closer to Said. Whereas the actions that 'savages' or 'neurotics' perform to maintain cohesion are subject to distortions or repressions because they fear the power of their own 
thoughts, the artist is 'performs something resembling the accomplishment of those desires' (Freud 2004:120). Where the former aim to retain distance from their thoughts, the artist tries to get as close as possible.

Just as Said argues that in The interpretation of dreams Freud was word and deed, so Said performs Orientalism in that text. To perform is to place oneself inside and outside a process, to watch oneself being watched, to anticipate supportive and antagonistic responses. Dialectically, he recognises that a polemical or 'antithetical' text like Orientalism needs an appropriate thesis. He also says that he cannot stand outside Orientalism; he means that he (and we) cannot think beyond the boundary of a discourse that constructs us: one cannot 'devise an inclusive interpretive methodology that could hang free of the precisely concrete historical circumstances out of which Orientalism derived and from which it drew sustenance' (2013a:354). One reason for this is that it existed before it was named and could be projected onto past, present and future. That much it shares with Freud's reliance on 'pre-historical' for which there is no record, but which he believes must have existed in order for later recorded practices to make sense. However, Said clearly acts against Orientalism and can imagine something beyond it, and the same must apply to his relationship with Hellenism. Hellenism is then no longer the only logical point of departure and historical origin of Orientalism. One can think about the latter without Greek mythology and the myth of Greek self-sufficiency. Said, Downey and Tourney all place Freud in the Greece of Homer, the polis, Aeschylus, Sophocles and Euripides, as does Freud himself. However, Armstrong proposes an alternative identification with the 'inclusive imperialist Hellenism' (p. 107, emphasis in original) of Alexander the Great, which comes after the polis, and was briefly imperial but never exclusive. This suggestion directs us towards a more cosmopolitan, complex identity that more readily embraces the East, because it acknowledges the East as a necessary and supportive part of itself.

Freud and Said, the two writers who have been my main concern, and several of those who have received less attention, draw on some form of latency to facilitate 'knowledge of a different kind' (Said 1985a:169; emphasis in original) In Freud, latency and the return of the repressed are necessary conditions for individual and social development. For Kuhn too, latency and the return of the repressed occur when the successor suppresses elements of an earlier paradigm; they re-emerge when that paradigm is in turn replaced (206-207). Bernal, following Kuhn, sought to demonstrate that there is greater continuity between the Ancient and Revised Ancient Models than either has with the interstitial Aryan Model. Where Bernal's narrative traces some of the intellectual foundations of fascism in Hellenism, Said is concerned with fascism's post-Holocaust repetition in Israel. Both search for an enabling force or voice that makes it possible for a new paradigm to emerge, to become 'normal' in a Kuhnian sense. In both cases, the new paradigm emerges by suppressing the suppressive aspects of the old paradigm, and these writers seek to incorporate aspects of the preceding paradigms so that the histories they propose and the societies they envisage can accommodate and tolerate a greater range of different differences, not merely the differences that the old paradigm manufactures for itself.

\section{Acknowledgements Competing interests}

The authors declare that they have no financial or personal relationships which may have inappropriately influenced them in writing this article.

\section{References}

Aeschylus, 472 B.C.E., The Persians, transl. R. Potter, viewed 30 March 2014, from http://classics.mit.edu/Aeschylus/persians.html

Arendt, H. [1948] 2007, 'To save the Jewish homeland', in J. Cohn \& E.H. Feldman (eds.), Hannah Arendt: The Jewish writings, pp. 388-401, Schoken Books, New York.

Armstrong, R., 2005, A Compulsion for antiquity: Freud and the ancient world, Cornell University Press, Ithaca.

Bernal, M., 1978, Black Athena: The Afroasiatic roots of classical civilization, Vol. I, Rutgers University Press, New Brunswick.

Copi, I.M., 1973, Introduction to logic, Collier Macmillan, New York.

Downing, C., 1975, 'Sigmund Freud and the Greek mythological tradition', Journal of the American academy of religion 43(1), 3-14.

Euripides, 410 B.C.E., Iphigenia at Aulis, viewed 30 March 2014, from http://classics. mit.edu/Euripides/iphi_aul.html

Euripides, 410 B.C.E., The Bacchae, transl. G. Murray, viewed 30 March 2014, from http://classics.mit.edu/Euripides/bacchan.html

Freud, S., 1939, Moses and monotheism, transl. K. Jones, Hogarth Press, London.

Freud, S., 1978, The Interpretation of dreams, transl. J. Strachey, Penguin, Harmondsworth.

Freud, S., 1979, Civilization and its discontents, transl. J. Riviere, Hogarth Press, London.

Freud, S., 1991, 'A disturbance of memory on the Acropolis', transl. J. Strachey, in J. Strachey (ed.), The standard edition of the complete psychological works of Sigmund Freud, Vol. XXII, pp. 237-248, Hogarth Press, London.

Freud, S., 2004, Totem and taboo: Some points of agreement between the mental life of savages and neurotics, transl. J. Strachey, Routledge, London.

Guttenplan, S., 1996, The languages of logic, Blackwell, Oxford.

Habermas, J., 1979, 'Modernity: An unfinished project', transl. N. Walker, in M.P. de'Entreves \& S. Benhabib (eds.), Habermas and the unfinished project of modernity, pp. 3-15, Massachusetts Institute of Technology Press, Cambridge.

Hamilakis, Y., 2007, The nation and its ruins: Antiquity, archaeology, and the national imagination in Greece, Oxford University Press, New York.

Homer, 2009, The Iliad, transl. R. Lattimore, University of Chicago Press, Chicago.

Kuhn, T., 1970, The structure of scientific revolutions, University of Chicago Press, Chicago.

Lacan, J., 1992, 'The function and field of speech and language in psychoanlysis', transl. A. Sheridan, in Écrits: A selection, pp. 30-113, Tavistock/Routledge, London.

Morrison, T., 1988, Unspeakable things unspoken: The Afro-American presence in American literature, viewed 4 September 2014, from http://tannerlectures.utah. edu/_documents/a-to-z/m/morrison90.pdf

Roynon, T., 2013, Toni Morrison and the classical tradition: Transforming American culture, Oxford University Press, Oxford.

Said, E., 1985a, Beginnings: Intention and method, Columbia University Press, New York.

Said, E., 1985b, Orientalism, Penguin, Harmondsworth.

Said, E., 1993, Culture and imperialism, Chatto and Windus, London.

Said, E., 2004, Freud and the non-European, Verso, London.

Said, E., 2007, On late style: Music and literature against the grain, Vintage, New York.

Said, E., 2013a, 'Representing the colonized: Anthropology's interlocutors', in E. Said (ed.), Reflections on exile and other literary and cultural essays, pp. 348-373, Granta, London.

Said, E., 2013b, 'The clash of definitions', in E. Said (ed.), Reflections on exile, pp. 569-592, Harvard University Press, Cambridge.

Tourney, G., 1965, 'Freud and the Greeks: A study of the influence of classical Greek mythology and philosophy upon the development of Freudian thought', Journal of the History of the Behavioral sciences 1(1), 67-85.

Yeats, W.B., 1976, Collected poems, Macmillan, London. 